\title{
Species Diversity of Entomopathogenic Fungi Infecting the Sugarcane Aphid Melanaphis sacchari: A Recently Introduced Pest in Mexico
}

\author{
Jorge Zambrano-Gutiérrez ${ }^{1}$, Raquel Alatorre-Rosas ${ }^{1 *}$, María G. Carrillo-Benítez ${ }^{1}$, \\ J. Refugio Lomelí-Flores ${ }^{1}$, Remigio A. Guzmán-Plazola1, Ausencio Azuara-Domínguez², \\ Antonio P. Terán-Vargas ${ }^{3}$ \\ ${ }^{1}$ Programa de Fitosanidad, Colegio de Postgraduados, Texcoco, Mexico \\ ${ }^{2}$ Posgrado en Biología, Instituto Tecnológico de Ciudad Victoria, Ciudad Victoria, Mexico \\ ${ }^{3}$ Instituto Nacional de Investigaciones Forestales, Agrícolas y Pecuarias, Campo Experimental Las Huastecas, Cuauhtémoc, \\ Mexico \\ Email: ^alatoros@colpos.com
}

\begin{abstract}
How to cite this paper: Zambrano-Gutiérrez, J., Alatorre-Rosas, R., Carrillo-Benítez, M.G., Lomelí-Flores, J.R., Guzmán-Plazola, R.A., Azuara-Domínguez, A. and Terán-Vargas, A.P. (2019) Species Diversity of Entomopathogenic Fungi Infecting the Sugarcane Aphid Melanaphis sacchari: A Recently Introduced Pest in Mexico. Advances in Microbiology, 9, 38-55
\end{abstract}

https://doi.org/10.4236/aim.2019.91004

Received: December 12, 2018

Accepted: January 11, 2019

Published: January 14, 2019

Copyright $\odot 2019$ by author(s) and Scientific Research Publishing Inc. This work is licensed under the Creative Commons Attribution International License (CC BY 4.0).

http://creativecommons.org/licenses/by/4.0/

CC) (i) Open Access

\begin{abstract}
The sugarcane aphid, Melanaphis sacchari, is a key pest that affects sorghum in Mexico. During 2014 to 2016, in South of Tamaulipas sites and Bajio region in Guanajuato, the populations of this aphid were infected by different species of Hypocrealean fungi. Based in the morphometric identification and molecular characterization, the species associated with sugarcane aphid in South of Tamaulipas were Lecanicillium longisporum, Beauveria bassiana and Isaria javanica. In this region, the higher infection levels were caused by L. longisporum, mortality range from $30.0 \%$ to $50.0 \%$. The presence of $I$. javanica and $B$. bassiana represented less than $26.0 \%$ and $10.0 \%$, respectively. In Guanajuato, the species found corresponded to L. longisporum and B. bassiana. The infection levels of both species in sugarcane aphid populations in Guanajuato sites were less than $1.00 \%$. The natural occurrence of entomopathogenic fungi on sugarcane aphid populations was associated with climactic factors such as temperature and relative humidity and development of infections was possibly affected by abiotic factors such as crop phenological stage and applications of chemical insecticides realized by farmers for control of this aphid. Further studies on the ecology and physiology of these fungi and trials to determine virulence and persistence in $M$. sacchari populations are needed. This is the first report on natural presence of L. longisporum, B. bassiana and $I$. javanica causing disease on Melanaphis sacchari in Guanajuato and Tamaulipas, Mexico.
\end{abstract}




\section{Keywords}

Aphid, Sorghum, Hypocrealean Fungi, Native Isolates, Identification

\section{Introduction}

The sugarcane aphid (SCA) Melanaphis sacchari (Zehntner) (Hemiptera: Aphididae) is an invasive species and the most important insect pest of Sorghum spp. in Mexico and the United States of America [1] [2] [3]. This aphid can infest sorghum in all its stages of development and cause production losses of 20 to $100 \%$ [1] [2] [4]. The foliar application of chemical insecticides such as imidacloprid, spirotetramat, thiamethoxam, sulfoxaflor, and fluopyradifurone is themain strategy to control SCA [1] [2] [5]. However, the inadequate management of these chemicals in the field can induce the development of resistance in $M$. sacchari populations. This situation has been documented in other Aphididae species with some of the insecticides used for the control of SCA [6] [7] [8]. Thus, other strategies such as sorghum genotypes tolerant to M. sacchari have been evaluated [9] [10] [11] [12]. Predators, parasitoids, and species of entomopathogenic fungi (EPF) such as Lecanicillium lecanii (Zimm.) Zare and Gams and L. longisporum (Petch) Zare and Gams can offer a sustainable control $M$. sacchari populations [2] [13] [14] [15]. EPF is the most important organism for the biological control of aphids; however their infection on insect populations can be regulated by climatic conditions such as temperature, relative humidity, rain, and wind [16] [17] [18]. Worldwide, L. longisporum and L. lecanii have been reported causing epizooties in SCA populations [15] [19]. Other genera such as Beauveria, Isaria and several species of Entomophthorales can infect other species of aphids [16] [20]. Given the recent introduction of this pest in Mexico, it is important to look for species of fungi that are infecting this pest in the most important sorghum producing areas, in order to look for (in future works) candidates for their microbial control. Thus, we identified the species of EPF which were infecting the sugarcane aphid in some regions of Tamaulipas and Guanajuato, in first states infested by M. sacchari in Mexico.

\section{Materials and Methods}

\subsection{Study Area}

The study was carried out on agricultural fields of commercial sorghum in different phenological stages planted in Tamaulipas and Guanajuato. For sampling in Tamaulipas, populations of the sugarcane aphid were monitored in December 2014 as well as February, March, and May 2015 in sorghum crops of the autumn-winter cycle located in the municipalities of Aldama, Altamira, and Mante. Samples in Guanajuato were collected during the spring to summer of 2016 in the municipalities of Irapuato, Jaral del Progreso, and Salvatierra (Table 1). 
Table 1. Geographic location and phenological stage of the crops of sorghum with presence of entomopathogenic fungi associated with sugarcane aphid in Tamaulipas and Guanajuato.

\begin{tabular}{|c|c|c|c|c|}
\hline Isolate $^{\dagger}$ & $\begin{array}{l}\text { Geographic } \\
\text { location }\end{array}$ & $\begin{array}{l}\text { Collection } \\
\text { date }\end{array}$ & Sampled sites & $\begin{array}{l}\text { Phenological } \\
\text { stage of crop }\end{array}$ \\
\hline \multicolumn{5}{|c|}{ Lecanicillium sp. } \\
\hline CP-Llon1PAS & $\begin{array}{c}20^{\circ} 09^{\prime} 02.6^{\prime \prime} \mathrm{N} \\
100^{\circ} 53^{\prime} 06.9^{\prime \prime} \mathrm{W}\end{array}$ & 01/09/2016 & $\begin{array}{l}\text { San Antonio Eménguaro, } \\
\text { Salvatierra, Guanajuato }\end{array}$ & Boot stage $e^{\star *}$ \\
\hline CP-Llon2PAS & $\begin{array}{l}20^{\circ} 25^{\prime} 21.6^{\prime \prime} \mathrm{N} \\
101^{\circ} 01^{\prime} 31.5^{\prime \prime} \mathrm{W}\end{array}$ & $01 / 09 / 2016$ & $\begin{array}{l}\text { Cerrito de Camargo, Jaral del } \\
\text { Progreso, Guanajuato }\end{array}$ & $\begin{array}{l}\text { Hard dough } \\
\text { stage }^{*}\end{array}$ \\
\hline CP-Llon3PAS & $\begin{array}{c}20^{\circ} 38^{\prime} 43.8^{\prime \prime} \mathrm{N} \\
101^{\circ} 17^{\prime} 59.7^{\prime \prime} \mathrm{W}\end{array}$ & $25 / 08 / 2016$ & $\begin{array}{l}\text { Distrito de Riego 011, } \\
\text { Irapuato, Guanajuato }\end{array}$ & $\begin{array}{l}\text { Soft dough } \\
\text { stage* }^{*}\end{array}$ \\
\hline CP-Llon4PAS & $\begin{array}{l}22^{\circ} 31^{\prime} 57.9^{\prime \prime} \mathrm{N} \\
98^{\circ} 12^{\prime} 17.5^{\prime \prime} \mathrm{W}\end{array}$ & $26 / 12 / 2014$ & $\begin{array}{l}\text { Cuauhtémoc, Altamira, } \\
\text { Tamaulipas (Plot A) }\end{array}$ & Flowering* \\
\hline CP-Llon5PAS & $\begin{array}{l}22^{\circ} 27^{\prime} 46.5^{\prime \prime} \mathrm{N} \\
98^{\circ} 04^{\prime} 58.6^{\prime \prime} \mathrm{W}\end{array}$ & $26 / 12 / 2014$ & $\begin{array}{l}\text { Cervantes, Altamira, } \\
\text { Tamaulipas }\end{array}$ & $\begin{array}{l}\text { Flag leaf } \\
\text { visible }\end{array}$ \\
\hline CP-Llon6PAS & $\begin{array}{l}22^{\circ} 36^{\prime} 09.6^{\prime \prime} \mathrm{N} \\
98^{\circ} 12^{\prime} 06.0^{\prime \prime} \mathrm{W}\end{array}$ & $26 / 12 / 2014$ & $\begin{array}{l}\text { Cuauhtémoc, Altamira, } \\
\text { Tamaulipas (Plot B) }\end{array}$ & $\begin{array}{l}\text { Soft dough } \\
\text { stage }^{\star *}\end{array}$ \\
\hline \multicolumn{5}{|c|}{ Beauveria sp. } \\
\hline CP-Bb1PAS & $\begin{array}{c}20^{\circ} 25^{\prime} 21.6^{\prime \prime} \mathrm{N} \\
101^{\circ} 01^{\prime} 31.5^{\prime \prime} \mathrm{W}\end{array}$ & $01 / 09 / 2016$ & $\begin{array}{l}\text { Cerrito de Camargo, Jaral del } \\
\text { Progreso, Guanajuato }\end{array}$ & $\begin{array}{l}\text { Hard dough } \\
\text { stage }^{*}\end{array}$ \\
\hline CP-Bb2PAS & $\begin{array}{l}20^{\circ} 25^{\prime} 21.6^{\prime \prime} \mathrm{N} \\
101^{\circ} 01^{\prime} 31.5^{\prime \prime} \mathrm{W}\end{array}$ & 01/09/2016 & $\begin{array}{l}\text { Cerrito de Camargo, Jaral del } \\
\text { Progreso, Guanajuato }\end{array}$ & $\begin{array}{l}\text { Hard dough } \\
\text { stage* }^{*}\end{array}$ \\
\hline CP-Bb3PAS & $\begin{array}{l}22^{\circ} 32^{\prime} 22.1^{\prime \prime N} \\
98^{\circ} 08^{\prime} 17.1^{\prime \prime} \mathrm{W}\end{array}$ & $13 / 03 / 2015$ & $\begin{array}{l}\text { Cuauhtémoc, Altamira, } \\
\text { Tamaulipas (Plot C) }\end{array}$ & $\begin{array}{l}\text { Hard dough } \\
\text { stage }^{\star *}\end{array}$ \\
\hline CP-Bb4PAS & $\begin{array}{l}22^{\circ} 30^{\prime} 01.8^{\prime \prime} \mathrm{N} \\
98^{\circ} 34^{\prime} 21.4^{\prime \prime} \mathrm{W}\end{array}$ & 06/05/2015 & $\begin{array}{l}\text { Los Aztecas, Mante, } \\
\text { Tamaulipas }\end{array}$ & $\begin{array}{l}\text { Physiological } \\
\text { maturity* }\end{array}$ \\
\hline \multicolumn{5}{|c|}{ Isaria sp. } \\
\hline CP-Ija1PAS & $\begin{array}{l}22^{\circ} 45^{\prime} 28.1^{\prime \prime} \mathrm{N} \\
98^{\circ} 07^{\prime} 07.3^{\prime \prime} \mathrm{W}\end{array}$ & 08/05/2015 & $\begin{array}{c}\text { Higinio Tanguma, Aldama, } \\
\text { Tamaulipas }\end{array}$ & Flowering* \\
\hline CP-Ija2PAS & $\begin{array}{l}22^{\circ} 32^{\prime} 49.3^{\prime \prime} \mathrm{N} \\
98^{\circ} 34^{\prime} 13.6^{\prime \prime} \mathrm{W}\end{array}$ & 06/05/2015 & $\begin{array}{c}\text { Tantoyuquita, Mante, } \\
\text { Tamaulipas }\end{array}$ & $\begin{array}{l}\text { Physiological } \\
\text { maturity* }\end{array}$ \\
\hline
\end{tabular}

$\mathrm{N}=$ North latitude. $\mathrm{W}=$ West longitude. ${ }^{\dagger}$ Isolates obtained from naturally infected individuals of SCA. ${ }^{\text {It }}$ was determined at the time of sampling in field based in the established by Vanderlip and Reeves [21]. The samplings were carried on: ${ }^{*}$ Commercials hybrids or varieties and ${ }^{* *}$ Soca of sorghum.

\subsubsection{Sampling of Aphid Populations}

Within each location, five sampling points were established $(5 \times 5 \mathrm{~m}$ at each point). There were four points in the corners and one in the middle of each plot. At each point, one sample of 10 sorghum leaves was randomly selected and the number of fungal infected and healthy aphids was recorded. Due to the difficulty of identifying fungal pathogens in the field, infected aphids were collected in plastic containers with an airtight lid ( $15 \mathrm{~cm}$ wide by $7 \mathrm{~cm}$ deep). These containers were labeled and then kept at $10^{\circ} \mathrm{C}$ for 72 hours until processing. Growth stage of the crop was recorded on each sampling occasion using the growth stages for sorghum proposed by Vanderlip and Reeves [21]. 


\subsubsection{Weather Data}

The local temperature, precipitation, and relative humidity (RH) data before sampling were obtained from the local weather station of the National Institute of Forestry, Agriculture and Livestock (INIFAP) (Table 4).

\subsection{Isolation of Entomopathogenic Fungi Infecting the Sugarcane Aphid}

The EPF Hypocreales were isolated using the rain conidia descending method proposed by Papierok and Hajek [22] for Entomopthoralean fungi with some modifications. The mycosed aphids were adhered individually with a double-sided adhesive tape to the lid of a 60 -mm-diameter Petri dish with $10 \mathrm{~mL}$ of Papa Dextrose Agar (PDA: BD Bioxon, Becton Dickinson of Mexico S. A. de C. V., Cuautitlán Izcalli, state of Mexico). The dishes were incubated at $25^{\circ} \mathrm{C} \pm 2^{\circ} \mathrm{C}$ in the dark inside a bioclimatic chamber (Thermo Fisher Scientific, Model 3721. Marietta, OH, USA) until colonies developed. Each isolate was purified as monosporic culture and incubated for 15 days at the conditions described above.

\subsection{Morphological Characterization}

For morphological studies of EPF genus, isolates were grown on PDA at $25^{\circ} \mathrm{C} \pm$ $2^{\circ} \mathrm{C}$ for 15 days. Common saprophytic species were excluded from this research. These included species from the genera Penicillium, Cladosporium, Mucor, and Aspergillus. For detailed morphological comparisons, the characteristics of the colony were described along with the size and shape of the conidia and conidiogenous cells. To determine the shape and size of conidia and conidiogenous cells, microcultures were grown on PDA incubated at $25^{\circ} \mathrm{C} \pm 2^{\circ} \mathrm{C}$ in the dark for 10 to 15 days until sporulation was evident. After incubation, images of conidia and conidiogenous cells were photographed with a photomicroscope (Leica DM750; Leica Microsystems, Heerbrugg, Switzerland) at 40× with a Leica Application Suite program version 3.0.0. Images were processed with GIMP version 2.8 (GNU Image Manipulation Program). ImageJ version 3.00 was used to measure the structures. For each isolate, a total of 100 independent measurements of conidia and conidiogenous cells were made. All isolates were stored at $-80^{\circ} \mathrm{C}$ in $2 \mathrm{~mL}$ cryovials containing $10 \%$ sterile glycerol.

\subsection{Genetic Characterization}

\subsubsection{DNA Extraction}

For genomic DNA extraction, each isolate was grown on a layer of sterile sweet cellophane paper (Stationery Lumen S. A. de C. V. Mexico City, México) placed on top of PDA. Plates were incubated at $25^{\circ} \mathrm{C} \pm 2{ }^{\circ} \mathrm{C}$ for 15 days in complete darkness. After the incubation period, the mycelium was harvested and transferred to sterile $20 \mathrm{~mL}$ vials and lyophilized for $48 \mathrm{~h}$ using a freeze dryer (FreeZone 4.5, Labconco Coporation. Kansas City, Missouri, USA). For the DNA extraction, $0.2 \mathrm{~g}$ of lyophilized mycelium was deposited in $1.5 \mathrm{~mL}$ Eppendorf tube with $1 \mathrm{~mL}$ of liquid nitrogen and then was macerated using a No. 14 knitting 
hook (Fabrics Parisina S. A. de C. V. Texcoco, State of Mexico, Mexico). Total genomic DNA was extracted with the DNeasy ${ }^{\oplus}$ PlantMinikit following the manufacturer's instructions with some modifications [23]. DNA concentration was quantified using a spectrophotometer NanoDrop ${ }^{\mathrm{TM}}$ 2000/2000 C (Thermo Fisher Scientific, Inc. Waltham, MA, USA), and the samples were stored at $-20^{\circ} \mathrm{C}$ until used.

\subsubsection{Amplification and Sequencing}

For the phylogenetic placement of the genus of each isolate, the ITS1/5.8S rDNA/ITS2 region was amplified using the Polymerase chain reaction (PCR) [24]. PCR conditions consisted of an initial denaturation at $94^{\circ} \mathrm{C}$ for 5 minutes followed by 35 cycles of denaturation at $94^{\circ} \mathrm{C}$ for 60 seconds, annealing at $55^{\circ} \mathrm{C}$ for 60 seconds, and extension at $72^{\circ} \mathrm{C}$ for 90 seconds; the final extension was at $72^{\circ} \mathrm{C}$ for 7 minutes.

For Lecanicillium sp. isolates, the PCR mix for ITS region contained $30 \mathrm{ng}$ of genomic DNA, $1 \times$ PCR reaction buffer, $3.0 \mathrm{mM} \mathrm{MgCl}, 0.6 \mathrm{mM}$ dNTPs mix (QIAGEN GmbH, Hilden, Germany), $0.6 \mathrm{mM}$ of each primer, and 2.5 U Taq DNA Polymerase (BIOLASE ${ }^{\mathrm{TM}}$ ).

The mixture reaction for ITS region of Beauveria sp. was performed with 20 ng of genomic DNA, $1 \times$ PCR reaction buffer, $2.0 \mathrm{mM} \mathrm{MgCl}_{2}, 0.2 \mathrm{mM}$ dNTP's mix, $0.4 \mathrm{mM}$ of each primer, and $2 \mathrm{U}$ Taq DNA Polymerase.

The PCR reaction mixture for Isaria sp. consisted of $80 \mathrm{ng}$ of genomic DNA, $1 \times$ PCR reaction buffer, $2.0 \mathrm{mM} \mathrm{MgCl}_{2}, 1.0 \mathrm{mM}$ dNTP's mix, $1.0 \mathrm{mM}$ of each primer, and 2.5 U Taq DNA Polymerase.

For species identification were amplified the $18 \mathrm{~S}$ rDNA region and $\mathrm{Bt} 2$ of the $\beta$-tubulin gen in the isolates of Lecanicillium [25]. The mitochondrial intergenic region atp9-nad3 and Bloc in the isolates of Beauveria [26] [27]. The small subunit ribosomal ribonucleic acid (SSU rRNA) was amplified in the isolates of Isaria [28]. The amplification of each region was realized using the primers indicated in Table 2.

The PCR mixture for $18 \mathrm{~S}$ rDNA region and $\mathrm{Bt} 2$ of the $\beta$-tubulin were performed with $50 \mathrm{ng}$ of DNA genomic, $1 \times$ PCR reaction buffer, $1.5 \mathrm{mM} \mathrm{MgCl}_{2}$, $0.2 \mathrm{mM}$ dNTP's mix (QIAGEN GmbH, Hilden, Germany), $0.6 \mathrm{mM}$ of each primer, and $1 \mathrm{U}$ Taq DNA Polymerase. For both regions, the amplification conditions included an initial denaturation at $94^{\circ} \mathrm{C}$ for 5 minutes; 35 cycles of denaturation at $94^{\circ} \mathrm{C}$ for 60 seconds, annealing at $55^{\circ} \mathrm{C}$ for 60 seconds, and extension at $72^{\circ} \mathrm{C}$ for 60 seconds with a final extension at $72^{\circ} \mathrm{C}$ for 10 minutes.

The mitochondrial intergenic region atp9-nad3 was amplified using $50 \mathrm{ng}$ of genomic DNA, $1 \times$ PCR reaction buffer, $3.0 \mathrm{mM} \mathrm{MgCl}{ }_{2}, 0.6 \mathrm{mM}$ dNTPs mix, $0.6 \mathrm{mM}$ of each primer, and $2 \mathrm{U}$ Taq DNA Polymerase. The amplification program included an initial denaturation at $95^{\circ} \mathrm{C}$ for 5 minutes, 30 cycles of denaturation at $95^{\circ} \mathrm{C}$ for 30 seconds, annealing at $55^{\circ} \mathrm{C}$ for 30 seconds, extension at $72^{\circ} \mathrm{C}$ for 60 seconds, and a final extension at $72^{\circ} \mathrm{C}$ for 7 minutes. The PCR reaction for Bloc region was performed with $50 \mathrm{ng}$ of genomic DNA, $1 \times$ PCR reaction 
Table 2. Primers used for PCR' amplification of regions of genomic DNA of entomopathogenic fungi associated with the sugarcane aphid.

\begin{tabular}{ccc}
\hline Region & Primers & Sequence (5' $^{\prime} \mathbf{3}^{\prime}$ ) \\
\hline \multirow{2}{*}{ ITS1/5.8S rDNA/ITS2 } & ITS5 & GGAAGTAAAAGTCGTAACAAGG \\
& ITS4 & TCCTCCGCTTATTGATATGC \\
18S rDNA & NS1 & GTAGTCATATGCTTGTCTC \\
& NS2 & GGCTGCTGGCACCAGACTTGC \\
\multirow{2}{*}{-tubulin } & Bt2a & GGTAACCAAATCGGTGCTGCTTTC \\
& Bt2b & ACCCTCAGTGTAGTGACCCTTGGC \\
intergenic mitochondrial region & nad3F & GAATTAGGTAAAGGAGCC \\
nad3-atp9 & atp9R & GAGAATAATTGATTTTTAATG \\
& B22U & GTCGCAGCCAGAGCAACT \\
Bloc & B822L & AGATTCGCAACGTCAACTT \\
& NS1 & GTAGTCATATGCTTGTCTC \\
SSU rDNA & FS2 & TAGGNATTCCTCGTTGAAGA \\
\hline
\end{tabular}

'All reactions of PCR were carried out in at a final volume of $25 \mu \mathrm{l}$.

buffer, $2.0 \mathrm{mM} \mathrm{MgCl}, 0.2 \mathrm{mM}$ dNTPs mix, $0.6 \mathrm{mM}$ of each primer, and $1 \mathrm{U}$ Taq DNA Polymerase. The amplification conditions for this region consisted of an initial denaturation at $94^{\circ} \mathrm{C}$ for 2 minutes; 40 cycles of denaturation at $94^{\circ} \mathrm{C}$ for 30 seconds, annealing at $56^{\circ} \mathrm{C}$ for 30 seconds, and extension at $72^{\circ} \mathrm{C}$ for 60 seconds; and a final extension at $72^{\circ} \mathrm{C}$ for 15 minutes.

The mixture reaction for SSU region was performed using the same mixture reaction described for amplification of ITS region for Isaria spp. isolates. Cycling conditions for the SSU rRNA region consisted of denaturation at $94^{\circ} \mathrm{C}$ for 2 minutes followed for 30 cycles of denaturation at $94^{\circ} \mathrm{C}$ for 60 seconds, annealing at $50^{\circ} \mathrm{C}$ for 60 seconds, and extension at $70^{\circ} \mathrm{C}$ for 3 minutes; the final extension was at $70^{\circ} \mathrm{C}$ for 2 minutes.

$\mathrm{PCR}$ reactions were performed at a final volume of $25 \mu \mathrm{l}$ using a $\mathrm{MyCycler}^{\mathrm{TM}}$ thermocycler (BIO-RAD Laboratories Inc. Hercules, California, USA). All amplification products were examined by electrophoresis in $1.5 \%$ agarose gel stained with ethidium bromide. Bands were visualized under UV light in a transluminator (Infinity-1000 WL/26 MX, Vilber Lourmat ${ }^{\oplus}$, Marne la Vallée, France). Samples were sent to Macrogen Inc. (Seoul, Korea) for sequencing with the primers used in the initial amplification.

\subsubsection{DNA Sequences Analysis}

For obtained the consensus sequences of amplified regions in each isolate, nucleotide sequences were edited and assembled with BioEdit v7.0.5 [29]. First, the consensus sequences of ITS region were compared with sequences from the GenBank database of the National Center for Biotechnology Information (NCBI) by Basic Local alignment search Tool (BLAST). For species identification, similar $18 \mathrm{~S}$ rDNA, $\mathrm{Bt} 2$ of the $\beta$-tubulin gen, mitochondrial intergenic region atp9-nad3, Bloc, and SSU rRNA sequences were selected of the NCBI and the European Bioinformatics Institute (EMBL-EBI). The select sequences of da- 
tabases and the amplified in the isolates were aligned with Mega 7.0 using Clustal W [30]. Phylogenetic analysis of aligned sequences was performed by Maximum Likelihood method (MLE), and the dendogram for each region was generated with a statistical analysis by Bootstrap [31] based on 1000 replications.

\section{Results}

\subsection{Morphological Identification}

The size of conidia and conidiogenous cells showed high variation between isolates of each genus (Table 3). Six isolates (CP-LlonPAS) were considered into the genus Lecanicillium; these had verticillated conidiogenous cells with a mucilaginous head and macro and micro ellipsoidal conidia with rounded ends. Conidial dimensions were of $3.25-7.91 \times 1.15-3.95 \mu \mathrm{m}$ (long $\times$ wide) and the size of conidiogenous cells was of $10.54-50.80 \times 1.02-2.75 \mu \mathrm{m}$. These characteristics are similar to descriptions documented in the literature for L. longisporum [15] [18] [32].

Colonies of the CP-BbPAS isolates had white mycelium with a powdery aspect and abundant sporulation. The micro cultures had short globose to flask-sharped conidiogenous cells that were clustered or whorled. The rachis was elongated and long in shape of zigzag after each conidium. The detached conidiogenous cells had a succession of global to round and densely packed conidia with average dimensions of 1.97 to $2.30 \times 1.65$ to $2.02 \mu \mathrm{m}$ (long $\times$ wide). The size of conidiogenous cells was of 3.84 to $3.94 \times 1.32$ to $1.49 \mu \mathrm{m}$ (long $\times$ wide). The morphological characteristics and the dimensions of the conidia and conidiogenous cells were similar to B. bassiana (Blas.) Vuill [33] [34] [35].

The CP-IjaPASisolates were characterized by his powdery appearance and white to gray coloration that changed to pink during sporulation. The shape of conidia was elongated with dimensions of 2.61 to $5.24 \times 1.35$ to $2.22 \mu \mathrm{m}$ (long $\times$ wide) and placed formed long chains. Conidiogenous cells have a globose basal portion with a narrow and long neck that connects with the conidia. These structures varying in size ranged of 3.63 to $8.37 \times 1.17$ to $2.55 \mu \mathrm{m}$ (long $\times$ wide). The macro and microscopic characteristics of those isolates are similar to that described for the genus Isaria. The dimensions of conidia and conidiogenous cells are similar to descriptions reported by others authors for $I$. javanica (Frieder. \& Bally) [36] [37].

\subsection{Molecular Analyses}

BLAST analysis showed that sequences ITS1/5.8S rDNA/ITS2 of the isolates CP-LlonPAS presented high similarity ( $94.0 \%$ to $99.0 \%)$ with some sequences corresponding to Lecanicillium species deposited in the GenBank. Phylogenetic tree for the sequences of the region $\mathrm{Bt} 2$ of $\beta$-tubulin gen showed that the CP-LlonPAS isolates were grouped within L. longisporum supported $80.0 \%$ bootstrap values (Figure 1(a)). Based in the phylogenetic analysis of 18S rDNA region, the six isolates CP-LlonPAS were grouped with L. longisporum 
Table 3. Conidial and conidiogenous cells measurements (in $\mu \mathrm{m} \pm \mathrm{SE}$ ) of L. longisporum, B. bassiana and I. javanica isolates of sugarcane aphid in Tamaulipas and Guanajuato, México.

\begin{tabular}{|c|c|c|c|c|}
\hline \multirow[b]{2}{*}{ Isolate } & \multicolumn{2}{|c|}{${ }^{* *}$ Conidia \pm SE } & \multicolumn{2}{|c|}{${ }^{* *}$ Conidiogenous cells $\pm \mathrm{SE}$} \\
\hline & $\begin{array}{c}\text { Length }^{\dagger} \\
(\text { Min - Max })^{g}\end{array}$ & $\begin{array}{c}\text { Wide }^{\dagger} \\
\text { (Min - Max) }\end{array}$ & $\begin{array}{c}\text { Length } \\
\text { (Min - Max) }\end{array}$ & $\begin{array}{c}\text { Wide } \\
\text { (Min - Max) }\end{array}$ \\
\hline \multicolumn{5}{|c|}{ Lecanicillium longisporum } \\
\hline CP-Llon1PAS & $\begin{array}{c}5.42 \pm 0.08 \\
(4.00-7.64)\end{array}$ & $\begin{array}{c}1.96 \pm 0.03 \\
(1.34-2.66)\end{array}$ & $\begin{array}{c}22.89 \pm 0.47 \\
(14.64-37.32)\end{array}$ & $\begin{array}{c}1.69 \pm 0.02 \\
(1.08-2.26)\end{array}$ \\
\hline CP-Llon2PAS & $\begin{array}{c}5.04 \pm 0.07 \\
(3.57-7.91)\end{array}$ & $\begin{array}{c}1.85 \pm 0.03 \\
(1.26-2.44)\end{array}$ & $\begin{array}{c}24.72 \pm 0.56 \\
(16.53-48.44)\end{array}$ & $\begin{array}{c}1.68 \pm 0.03 \\
(1.17-2.66)\end{array}$ \\
\hline CP-Llon3PAS & $\begin{array}{c}4.64 \pm 0.07 \\
(3.25-6.73)\end{array}$ & $\begin{array}{c}1.74 \pm 0.03 \\
(1.15-2.36)\end{array}$ & $\begin{array}{c}22.28 \pm 0.60 \\
(12.34-37.62)\end{array}$ & $\begin{array}{c}1.52 \pm 0.02 \\
(1.02-2.28)\end{array}$ \\
\hline CP-Llon4PAS & $\begin{array}{c}5.19 \pm 0.07 \\
(3.51-6.89)\end{array}$ & $\begin{array}{c}1.87 \pm 0.04 \\
(1.34-3.95)\end{array}$ & $\begin{array}{c}25.53 \pm 0.72 \\
(13.28-50.80)\end{array}$ & $\begin{array}{c}1.63 \pm 0.02 \\
(1.15-2.08)\end{array}$ \\
\hline CP-Llon5PAS & $\begin{array}{c}4.77 \pm 0.05 \\
(3.75-6.13)\end{array}$ & $\begin{array}{c}1.95 \pm 0.03 \\
(1.53-2.62)\end{array}$ & $\begin{array}{c}23.73 \pm 0.50 \\
(14.45-37.98)\end{array}$ & $\begin{array}{c}1.81 \pm 0.03 \\
(1.20-2.75)\end{array}$ \\
\hline CP-Llon6PAS & $\begin{array}{c}5.05 \pm 0.07 \\
(3.67-7.16)\end{array}$ & $\begin{array}{c}1.83 \pm 0.03 \\
(1.34-3.17)\end{array}$ & $\begin{array}{c}17.63 \pm 0.42 \\
(10.54-32.06)\end{array}$ & $\begin{array}{c}1.73 \pm 0.02 \\
(1.25-2.19)\end{array}$ \\
\hline$[15]^{\ddagger}$ & $7.54 \pm 1.27$ & $2.69 \pm 0.47$ & $25.87 \pm 6.04$ & $1.98 \pm 0.33$ \\
\hline$[18]^{\ddagger}$ & $4.50-8.50$ & $1.50-2.50$ & NA & NA \\
\hline$[31]^{\ddagger}$ & $5.00-10.5$ & $1.50-2.50$ & $20.00-40.00$ & $1.00-3.00$ \\
\hline \multicolumn{5}{|c|}{ Beauveria bassiana } \\
\hline CP-Bb1PAS & $\begin{array}{c}1.97 \pm 0.03 \\
(1.34-2.65)\end{array}$ & $\begin{array}{c}1.65 \pm 0.02 \\
(1.04-2.30)\end{array}$ & $\begin{array}{c}3.94 \pm 0.09 \\
(2.09-6.03)\end{array}$ & $\begin{array}{c}1.49 \pm 0.03 \\
(1.00-2.36)\end{array}$ \\
\hline $\mathrm{CP}-\mathrm{Bb} 2 \mathrm{PAS}$ & $\begin{array}{c}2.03 \pm 0.02 \\
(1.48-2.71)\end{array}$ & $\begin{array}{c}1.76 \pm 0.02 \\
(1.05-2.20)\end{array}$ & $\begin{array}{c}3.84 \pm 0.08 \\
(2.27-5.66)\end{array}$ & $\begin{array}{c}1.41 \pm 0.03 \\
(1.00-2.16)\end{array}$ \\
\hline CP-Bb3PAS & $\begin{array}{c}1.97 \pm 0.03 \\
(1.35-2.73)\end{array}$ & $\begin{array}{c}1.76 \pm 0.02 \\
(1.35-2.39)\end{array}$ & $\begin{array}{c}3.90 \pm 0.06 \\
(2.68-5.59)\end{array}$ & $\begin{array}{c}1.32 \pm 0.02 \\
(1.02-1.99)\end{array}$ \\
\hline $\mathrm{CP}-\mathrm{Bb} 4 \mathrm{PAS}$ & $\begin{array}{c}2.30 \pm 0.03 \\
(1.77-2.93)\end{array}$ & $\begin{array}{c}2.03 \pm 0.02 \\
(1.55-2.62)\end{array}$ & $\begin{array}{l}3.92 \pm 0.07 \\
(2.51-5.52)\end{array}$ & $\begin{array}{c}1.38 \pm 0.02 \\
(1.01-1.98)\end{array}$ \\
\hline$[32]^{\ddagger}$ & $1.81-3.10$ & $1.10-2.10$ & NA & NA \\
\hline$[33]^{\ddagger}$ & $2.00-3.00$ & $2.00-3.00$ & $3.00-6.00$ & NA \\
\hline$[34]^{\ddagger}$ & $2.00-3.00$ & NA & $3.00-6.00$ & NA \\
\hline \multicolumn{5}{|c|}{ Isaria javanica } \\
\hline CP-Ija1PAS & $\begin{array}{c}4.03 \pm 0.04 \\
(3.09-4.96)\end{array}$ & $\begin{array}{c}1.79 \pm 0.02 \\
(1.45-2.22)\end{array}$ & $\begin{array}{c}5.71 \pm 0.07 \\
(3.94-6.94)\end{array}$ & $\begin{array}{c}1.90 \pm 0.02 \\
(1.34-2.55)\end{array}$ \\
\hline CP-Ija2PAS & $\begin{array}{c}3.72 \pm 0.06 \\
(2.61-5.24)\end{array}$ & $\begin{array}{c}1.71 \pm 0.02 \\
(1.35-2.21)\end{array}$ & $\begin{array}{c}6.07 \pm 0.09 \\
(3.63-8.37)\end{array}$ & $\begin{array}{c}1.75 \pm 0.03 \\
(1.17-2.54)\end{array}$ \\
\hline$[35]^{\ddagger}$ & $3.00-6.30$ & $1.40-3.20$ & $5.10-10.90$ & $1.80-2.80$ \\
\hline$[36]^{\ddagger}$ & $4.24-4.92$ & $1.54-1.84$ & $5.15-5.53$ & $1.86-2.30$ \\
\hline
\end{tabular}

${ }^{\dagger}$ Mean for length and wide of conidia and conidiogenous cells $(n=100)$. ${ }^{\circ}$ Minimum and maximum values observed for each data set. ${ }^{*}$ Obtained from micro cultures development in PDA and incubated at $25^{\circ} \mathrm{C} \pm$ $2^{\circ} \mathrm{C}$ in darkness for 10 to 15 days. ${ }^{\ddagger}$ Dimensions reported by other authors and used as comparison data with those obtained in the present study. $\mathrm{SE}=$ Standard error. $\mathrm{NA}=$ Data no available. 


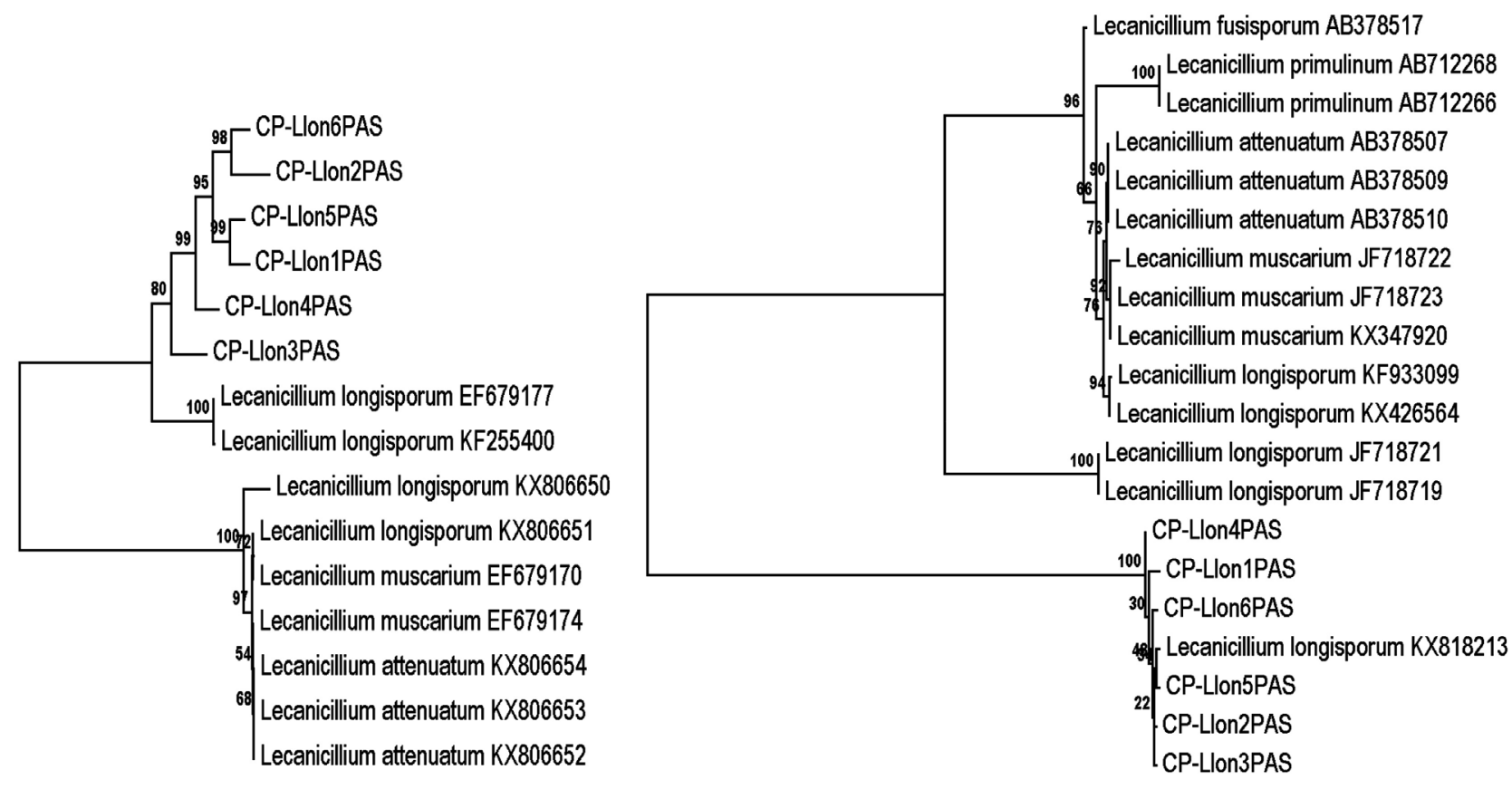

$\overparen{0.1}$

(a)

(b)

Figure 1. Phylogenetic trees for isolates of Lecanicillium longisporum: CP-Llon1PAS, CP-Llon2PAS, CP-Llon3PAS, CP-Llon4PAS, CP-Llon5PAS, and CP-Llon6PAS derived by Maximun Likelihood method with sequences of $\beta$-tubulina gen Bt2 region (a), and $18 \mathrm{~S}$ rDNA region (b). Bootstrap values based on 1000 replications. The analysis involved nine nucleotide sequences of $\beta$-tubulina gen $\mathrm{Bt} 2$ region (Bt2a-Bt2b) (a), and 14 sequences $18 \mathrm{~S}$ rDNA region (NS1-NS2) (b).

\section{(Figure 1(b)).}

The sequences ITS1/5.8S rDNA/ITS2 of the isolates CP-BbPAS exhibited high similarity with others homologous sequences of the specie $B$. bassiana placed in GenBank. Morphological identification of specie was confirmed with the phylogenetic analyses of the Bloc region, which showed that the four isolates were related with $B$. bassiana and a separated clade of other species such as $B$. brongniartii and $B$. caledonica (Figure 2(a)). This result was similar with the phylogenetic analyses of mitochondrial intergenic region nad3-atp9 in which isolates of Beauveria were grouped within the specie B. bassiana (Figure 2(b)).

The results of the BLAST analysis showed that sequences ITS1/5.8S rDNA/ITS2 of the isolates CP-Ija1PAS and CP-Ija2PAS presented between $97.0 \%$ to $99.0 \%$ of similarity with several species of genus Isaria. Phylogenetic tree indicated that both isolates were grouped within I. javanica supported by bootstrap value of 100.0\% (Figure 3).

\subsection{Natural Incidence of Mycosed Aphids}

The highest aphid mortality was caused by L. longisporum in the Tamaulipas sites, where the infection levels were $30.0 \%$ to $50.0 \%$, while in Guanajuato this specie represented less than $1.00 \%$. B. bassiana infected SCA populations in ranges of $6.0 \%$ to $10.0 \%$ in Tamaulipas sites; while this pathogen in Guanajuato 


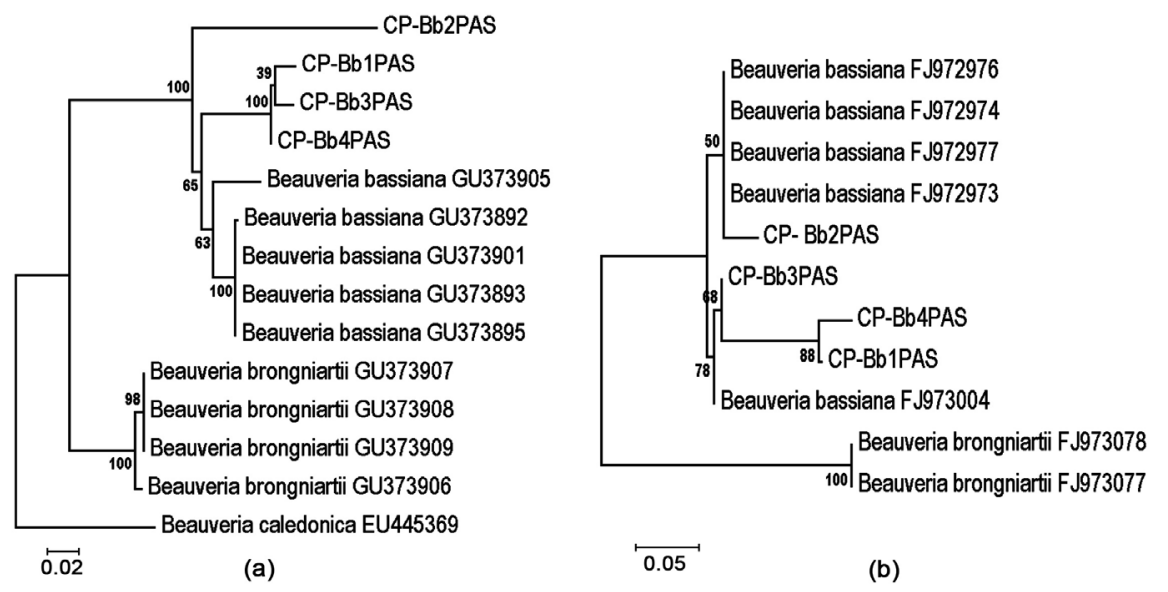

Figure 2. Phylogenetic trees for isolates of Beauveria bassiana: CP-Bb1PAS, CP-Bb2PAS, CP-Bb3PAS, and CP-Bb4PAS derived by maximum likelihood method with sequences of Bloc (a) and mitochondrial intergenic nad3-atp9 (b) regions. Bootstrap values based on 1000 replications. The analysis involved 10 nucleotide sequences of Bloc region (B22U-B822L) (a) and seven nucleotide sequences of mitochondrial intergenic nad3-atp9 region (nad3F-atp9R) (b).

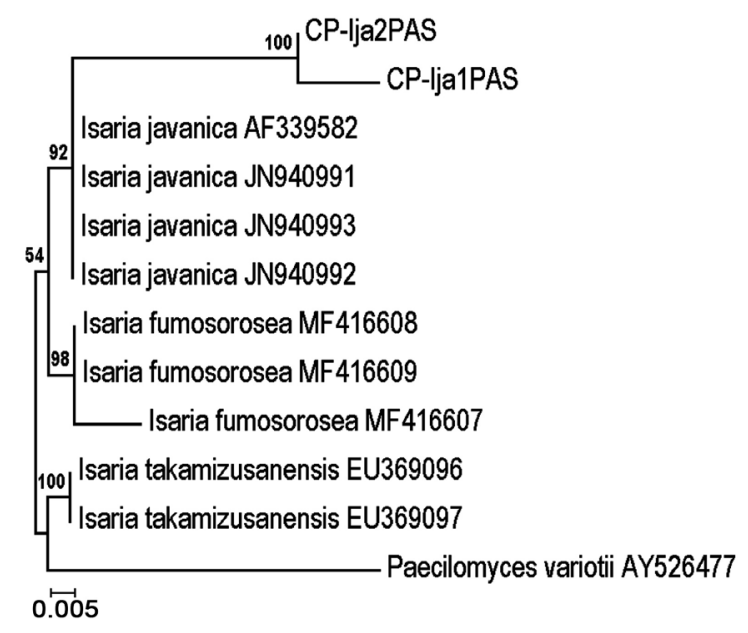

Figure 3. Phylogenetic trees for isolates of Isaria javanica: CP-IjaPAS and CP-Ija2PAS derived by Maximum Likelihood method with sequences of SSU region. Bootstrap values based on 1000 replications. The analysis involved 10 nucleotide sequences of SSU region (NS1-FS2).

showed low levels of infection. The presence of $I$. javanica was specific for Mante and Aldama, Tamaulipas; with infection range from $19.5 \%$ to $26.0 \%$ (Figure 4 ).

\subsection{Climatic Conditions in the Sampled Sites}

In Guanajuato, the infections for L. longisporum occurred after eight days with a mean value of $\mathrm{RH}$ of $68.0 \%$ to $88.0 \%$ and medium temperature of $19^{\circ} \mathrm{C}$ (Table 4). The presence of $L$. longisporum in the Tamaulipas sites was preceded by a period of $\mathrm{RH}$ higher than $87.0 \%$ and temperature range of $15^{\circ} \mathrm{C}$ to $24^{\circ} \mathrm{C}$ (Table 4). The natural presence of $B$. bassiana in Guanajuato and Tamaulipas was 


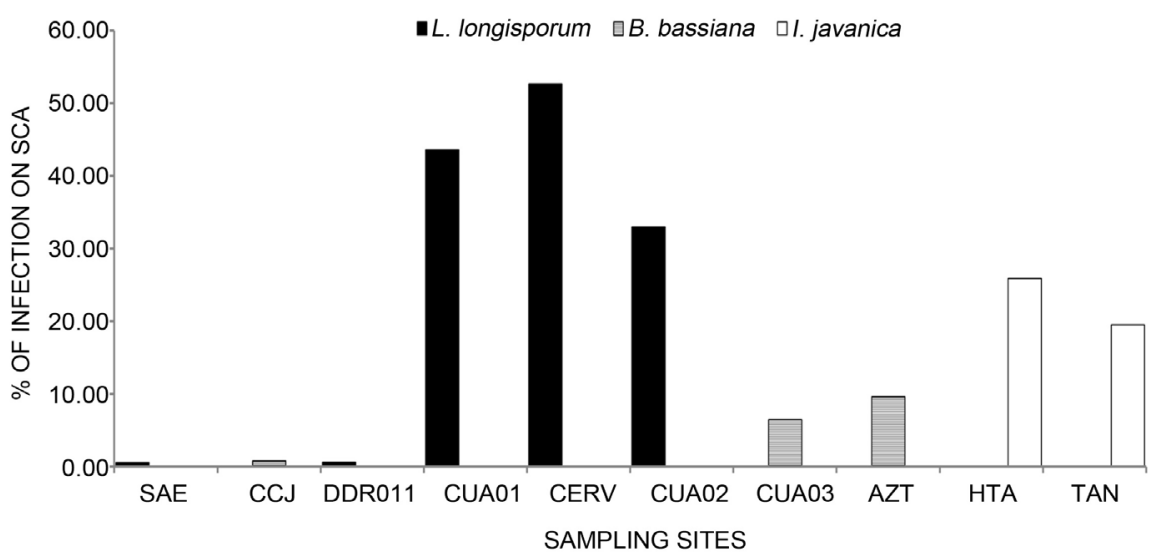

Figure 4. Natural presence of L. longisporum, B. bassiana, and I. javanica on populations of sugarcane aphid in Guanajuato and Tamaulipas. Sampled sites in Guanajuato: SAE (San Antonio Emenguaro), CCJ (Cerrito de Camargo), DDR011 (Distrito de riego 011). Sampled sites in Tamaulipas: CUA01 (Cuahutémoc, Plot A), CERV (Cervantes), CUA02 (Cuahutémoc, Plot B), CUA03, (Cuahutémoc, Plot C), AZTE (Los Aztecas), HTA (Higinıo Tanguma), TAN (Tantoyuquita).

Table 4. Meteorological recorded in the sites with presence of infected sugarcane aphid by entomopathogenic fungi in Guanajuato and Tamaulipas, México.

\begin{tabular}{|c|c|c|c|c|}
\hline \multirow{2}{*}{ Sampled site } & \multicolumn{4}{|c|}{ Meteorological data ${ }^{\dagger}$} \\
\hline & Max Tem & Min Tem & Med Tem & HR \\
\hline \multicolumn{5}{|c|}{ Guanajuato } \\
\hline San Antonio Emenguaro ${ }^{a}$ & 26.64 & 13.75 & 19.00 & 77.05 \\
\hline Cerrito de Camargo ${ }^{\mathrm{a}, \mathrm{b}}$ & 26.51 & 14.45 & 19.36 & 68.30 \\
\hline Distrito de riego $011^{\mathrm{a}}$ & 27.28 & 15.10 & 19.78 & 88.60 \\
\hline \multicolumn{5}{|c|}{ Tamaulipas } \\
\hline Cuahutemoc (Plot A and B) & 24.21 & 15.15 & 18.98 & 87.24 \\
\hline Cervantes $^{\mathrm{a}}$ & 23.00 & 15.80 & 18.96 & 88.67 \\
\hline Cuahutemoc (Plot C) & 23.39 & 13.24 & 17.50 & 81.36 \\
\hline Los Aztecas ${ }^{\mathrm{b}}$ & 30.75 & 18.84 & 24.43 & 69.88 \\
\hline Tantoyuquita $^{c}$ & 30.75 & 18.84 & 24.43 & 69.88 \\
\hline Higinio Tanguma $^{c}$ & 30.90 & 20.89 & 25.34 & 77.60 \\
\hline
\end{tabular}

${ }^{\dagger}$ Mean values of eight days before detection of L. longisporum, B. bassiana, and I. javanica on sugarcane aphid populations. Max Tem $=$ Maximum temperature $\left({ }^{\circ} \mathrm{C}\right)$. Min Tem $=$ Minimum temperature $\left({ }^{\circ} \mathrm{C}\right)$. Med Tem $=$ Medium temperature $\left({ }^{\circ} \mathrm{C}\right) . \mathrm{RH}=$ Relative humedad (\%). Sites with presence of: $L$. longisporum ${ }^{\mathrm{a}}$, B. bassiana ${ }^{\mathrm{b}}$ and I. javanica ${ }^{\mathrm{c}}$.

observed when the RH was from $68.0 \%$ to $81.0 \%$ with a mean temperature of $13^{\circ} \mathrm{C}$ to $30^{\circ} \mathrm{C}$ in the days before detection. The presence of aphids infected by $I$. javanica in Tamaulipas was remarkable when the temperature was $18^{\circ} \mathrm{C}$ to $30^{\circ} \mathrm{C}$ and $\mathrm{RH}$ from $69.0 \%$ to $77.0 \%$.

\section{Discussion}

The search for native species of EPF is important for implementing a microbial 
control strategy of the SCA. However, to establish a successful strategy it is important to know the exact identity of the EPF collected [37] [38]. Based on the morphological study (size and shape of the conidia and conidiogenous cells and characteristics of the colonies), the EPF isolates obtained in the Bajío region and southern Tamaulipas were grouped into three genera Lecanicillium (six isolates: CP-LlonPAS), Beauveria (four isolates: CP-BbPAS) and Isaria (two isolates: CP-IjaPAS). This classification was validated with a BLAST analysis that confirmed that the sequences ITS1/5.8S rDNA/ITS2 of the CP-LlonPAS, CP-BbPAS and CP-IjaPAS isolates showed high similarity with the homologous sequences of Lecanicillium, Beauveria and Isaria species deposited in the GenBank. For the morphological identification of the species, the dimensions of the conidia and the conidiogenous cells were determined. The dimensions of these structures in the isolates CP-LlonPAS, CP-BbPAS and CP-IjaPAS were similar to those documented by other authors for L. longisporum, B. bassiana and I. javanica or $I$. fumosorosea, respectively. However, morphological characteristics and classical taxonomic studies often do not provide sufficient evidence for species differentiation within each genus of EPF [39] [40] [41].

The identification of CP-LlonPAS isolates was confirmed with phylogenetic analysis of the regions $18 \mathrm{~S}$ rDNA and $\mathrm{Bt} 2$ of the $\beta$-tubulin gen. The combination of morphometric studies and phylogenetic analyses of the amplified regions confirm that the six CP-LlonPAS isolates belong to L. longisporum. This specie was previously reported as a natural regulator of SCA populations in Tecomán, Colima and on others aphids species in different regions worldwide [15] [18] [42]. Molecular identification of species within the Beauveria genus may be possible by sequencing of the mitochondrial intergenic region nad3-atp9 and Bloc [26] [27] [41]. The four CP-BbPAS isolates were identified as B. bassiana based in the combination of morphometric characteristics and molecular analysis of intergenic mitochondrial region nad3-atp9 and Bloc. The genus Beauveria is a common pathogen among several insect species of agricultural importance [34] including SCA. Based in the morphological studies, the isolates CP-IjaPAS belong to I. javanica or I. fumosorosea. BLAST analysis indicated that the isolates CP-IjaPAS presented high similarity with some sequences corresponding to I. javanica or I. fumosorosea. However, phylogenetic tree constructed with SSU rRNA region sequences grouped both isolates within I. javanica.

EPF natural infections on insect populations are regulated by biotic and abiotic factors, such as temperature, relative humidity, rain, wind, and cultural practices [16] [43] [44]. The climate in Tamaulipas is usually warm, dry, and temperate [45], the municipalities in which sampling was performed are located in the southern region near the Gulf of Mexico. This zone is characterized by tropical weather (Aw) with an annual average temperature highest to $18^{\circ} \mathrm{C}$ and a high percentage of humidity coming from the sea [45] [46]. In Guanajuato state, the aphid collections were from Celaya and Jaral del Progreso; these municipalities are part of the Bajio region that has a humid and temperate climate $(\mathrm{Cw})$ with an average annual rainfall of 600 to $800 \mathrm{~mm}$ [46]. It has been documented 
that $L$. longisporum causes infection in an average temperature range of $20^{\circ} \mathrm{C}$ to $25^{\circ} \mathrm{C}$ with a relative humidity greater than $70.0 \%$ in populations of $M$. sacchari, Brevicoryne brassicae (L.) and Myzus persicae (Sulzer) [15] [18]. Similar conditions were observed before the detection of aphids with mycosis in the sampling sites of Guanajuato and Tamaulipas. However, in Guanajuato infection levels were lower than $1.0 \%$. A similar situation was observed with the incidence of $B$. bassiana in Guanajuato and Los Aztecas, Tamaulipas; in these sites RH was less than $70.0 \%$.Conidia of $B$. bassiana require a relative humidity greater than $95.0 \%$ to germinate [44]. The highest incidence of B. bassiana was observed in Cuahutemoc, Tamaulipas, where the relative humidity was higher than $80.0 \%$, while that in the sites with low presence of infected aphids by $B$. bassiana the RH was less than $70.0 \%$. The presence of aphids infected by $I$. javanica in Tamaulipas was remarkable when the temperature was between $15^{\circ} \mathrm{C}$ to $33^{\circ} \mathrm{C}$ and the $\mathrm{RH}$ was $65.0 \%$ to $82.0 \%$. Some species of Isaria have thermotolerance, for example, $I$. javanica can develop at $35^{\circ} \mathrm{C}$ [47]. The CP-IjaPAS isolates, collected in Tamaulipas, might have this characteristic because they were collected in areas where the maximum temperature fluctuated from $30^{\circ} \mathrm{C}$ to $35^{\circ} \mathrm{C}$.

Others factors that may be related to the low levels of infection observed in Guanajuato are cultural practices and agrochemicals applications. The use of chemical fertilizers and insecticides affect the survival of EFP [16] [17]. Generally, when aphid population increases, producers apply insecticides by reducing the population of SCA. These control actions can prevent the propagation of the EFP species associated with this aphid, since low density can affect the potential of transmission and development of epizootics [16] [48]. Also, in some sites the detection of infected aphids was carried out during the physiological maturity stage of the crops when the presence of SCA was observed in isolated colonies on the leaves.

Adoption of these species for control of SCA will rely on achieving efficacy, cost reduction, and an ability to broaden the range of pest species that may be targeted. Detailed knowledge of fungal ecology is needed to better understand their role in nature and limitations in biological control. Testing under field conditions is required to identify effects of biotic and abiotic factors and their interactions on efficacy, persistence, and potential limitations to the use of these biocontrol agents in certain crops or locations. There are great opportunities to use these fungi in classical and conservation biological control approaches that can improve environmental stability, efficacy and the cost effectiveness. Temperature is one of the most important abiotic factors affecting the biology and ecology of entomopathogenic fungi [49] [50]. Therefore, the estimation of the in vitro growth profiles of entomopathogenic fungi is important in order to gain more information towards the understanding of the abiotic factors affecting specific diversity and distribution of fungal species.

\section{Conclusion}

The diversity and presence of EF associated with SCA was highest in Tamauli- 
pas, and wherein the species L. longisporum, B. bassiana and I. javanica were isolated. In Guanajuato, only the species of L. longisporum and B. bassiana were detected. B. bassiana and $I$. javanica represent the first record of other native species associated with $M$. sacchari. A more detailed study of the ecology of $L$. longisporum, B. bassiana and I. javanica within this agroecosystem is needed to analyze their possible role in the insect population dynamics.

\section{Acknowledgements}

We thank to Fundación Produce Guanajuato, A.C. for funding of the project and CONACyT for the scholarship awarded to the first author to support his doctoral studies. To Ariel W. Guzman, for their revision and suggestions to this manuscript. We are grateful with Fernando Tamayo Mejía (SDAyR Guanajuato) and Dionisio Díaz Martínez, Ulises A. Cabriales Vasquez, and Iván A. Delgado Robles (CESAVETAM), for their collaboration on field surveys in the states of Guanajuato and Tamaulipas.

\section{Conflicts of Interest}

The authors declare no conflicts of interest regarding the publication of this paper.

\section{References}

[1] Rodríguez del Bosque, L.A. and Terán A. (2015) Melanaphis sacchari (Hemiptera: Aphididae): A New Sorghum Insect Pest in Mexico. Southwestern Entomologist, 40, 433-434. https://doi.org/10.3958/059.040.0217

[2] Bowling, R.D., Brewer, M.J., Kerns, D.L., Gordy, J., Seiter, N., Elliott, N.E., Buntin, G.D., Way, M.O., Royer, T.A., Biles, S. and Maxson, E. (2016) Sugarcane Aphid (Hemiptera: Aphididae): A New Pest on Sorghum in North America. Journal of Integrated Pest Management, 7, 1-13. https://doi.org/10.1093/jipm/pmw011

[3] Medina, F.R., Armstrong, S.J. and Harrison, K. (2017) Genetic Population Structure of Sugarcane Aphid, Melanaphis sacchari, in Sorghum, Sugarcane, and Johnson Grass in the Continental USA. Entomologia Experimentalis et Applicata, 162, 358-365. https://doi.org/10.1111/eea.12547

[4] Delgado, R.C.S., Salas, A.M.D., Martínez, J.O.A., Díaz, G.J.A., Guzmán, M.R. and Salazar, S.E. (2016) Consumption of Melanaphis sacchari Zehntner (Hemiptera: Aphididae) by Hippodamia convergens (Coleopteran: Coccinellidae) and Chrysoperla carnea (Neuropteran: Chrysopidae). Entomologia Agricola, 3, 365-368.

[5] Bújanos, M.R., Marín, J.A. and Villalobos, R.S. (2016) Biological Effectiveness of Insecticides in Different Application Forms for the Control of the Sugarcane Aphid Melanaphis sacchari in the El Bajio Region, Mexico. In: Yañez-Lopez, R., Ed., Advances in Research on the Integrated Management of Sugarcane Aphid, Produce Guanajuato Foundation, Guanajuato, 116-128.

[6] Srigiriraju, L., Semtner, P.J. and Bloomquist, J.R. (2010) Monitoring for Imidacloprid Resistance in the Tobacco-Adapted Form of the Green Peach Aphid, Myzus persicae (Sulzer) (Hemiptera: Aphididae), in the Eastern United States. Pest Management Science, 66, 676-685.

[7] Ahmad, M. and Akhtar, S. (2013) Development of Insecticide Resistance in Field 
Populations of Brevicoryne brassicae (Hemiptera: Aphididae) in Pakistan. Journal of Economic Entomology, 106, 954-958. https://doi.org/10.1603/EC12233

[8] Matsuura, A. and Nakamura, M. (2014) Development of Neonicotinoid Resistance in the Cotton Aphid Aphis gossypii (Hemiptera: Aphididae) in Japan. Applied Entomology and Zoology, 49, 535-540. https://doi.org/10.1007/s13355-014-0289-4

[9] Sharma, H.C., Bhagwat, V.R., Daware, D.G., Pawar, D.B., Munghate, R.S., Sharma, S.P., Kumar, A.A., Reddy, B.V.S., Prabhakar, K.B. and Ambekar, S.S. (2014) Identification of Sorghum Genotypes with Resistance to the Sugarcane Aphid Melanaphis sacchari under Natural and Artificial Infestation. Plant Breeding, 133, 33-46. https://doi.org/10.1111/pbr.12111

[10] Armstrong, J.S., Rooney, W.L., Peterson, G.C., Villanueva, R.T., Brewer, M.J. and Sekula, O.D. (2015) Sugarcane Aphid (Hemiptera: Aphididae): Host Range and Sorghum Resistance including Cross-Resistance from Green Bug Sources. Journal of Economic Entomology, 108, 576-582. https://doi.org/10.1093/jee/tou065

[11] Mbulwe, L., Peterson, G.C., Armstrong, J.S. and Rooney, W. (2015) Registration of Sorghum Germplasm Tx3408 and Tx3409 with Tolerance to Sugarcane Aphid [Melanaphis sacchari (Zehntner)]. Journal of Plant Registrations, 10, 51-56. https://doi.org/10.3198/jpr2015.04.0025crg

[12] Pecina, Q.V., Herrera, C.C., Bújanos, M.R. and Hernández, M.M. (2016) Evaluation of the Agronomic Behavior and Resistance of Commercial Hybrids of Sorghum to Sugarcane Aphid Melanaphis sacchari (Zehntner) at Different Planting Dates in Guanajuato. In: Yañez-Lopez, R., Ed., Advances in Research on the Integrated Management of Sugarcane Aphid, Produce Guanajuato Foundation, Guanajuato, 130-137.

[13] Cortez, M.E., López, B.M., López, A.J.I., Orduño, C.F.J. and Herrera, R.G. (2016) Chrysopidae Species Associated with the Sugarcane Aphid in Northern Sinaloa, Mexico. Southwestern Entomologist, 41, 540-546.

[14] Rodriguez, V.J.M., Rodriguez, V.B., Sarmiento, C.M.A., Palomares, P.M. and Arredondo, B.H.C. (2016) Species of Coccinellidae (Coleoptera: Cucujoidea) Associated with Melanaphis sacchari Zehntner (Hemiptera: Aphididae) in Tamaulipas, Mexico. Entomological News, 126, 97-105. https://doi.org/10.3157/021.126.0205

[15] Berlanga, P.A.M., Ayala, Z.M.A., Gallou, A., Serna, D.M.G., Montesinos, M.R. and Arredondo, B.H.C. (2016) Identification of Lecanicillium longisporum Associate to Melanaphis sacchari (Hemiptera: Aphididae), in Sorghum. Revista Mexicana de Micologia, 44, 51-54.

[16] Steinkraus, D.C. (2006) Factors Affecting Transmission of Fungal Pathogens of Aphids. Journal of Invertebrate Pathology, 92, 125-131. https://doi.org/10.1016/j.jip.2006.03.009

[17] Scheepmaker, J.W.A. and Butt, T.M. (2010) Natural and Released Inoculum Levels of Entomopathogenic Fungal Biocontrol Agents in Soil in Relation to Risk Assessment and in Accordance with EU Regulations. Biocontrol Science and Technology, 20, 503-552. https://doi.org/10.1080/09583150903545035

[18] Baiswar, P., Madhukar, F.D., Ngachan, S., Chandra, S. and Azad-Thakur, N.S. (2016) Lecanicillium longisporum on Cabbage Aphid (Brevicoryne brassicae): A New Record from Northeast India. National Academy Science Letters, 39, 311-315. https://doi.org/10.1007/s40009-016-0452-2

[19] Haar, P.J., Bowling, R., Gardner, W.A. and Buntin, G.D. (2018) Epizootics of the Entomopathogenic Fungus Lecanicillium lecanii (Hypocreales: Clavicipitaceae) in Sugarcane Aphid (Hemiptera: Aphididae) Populations Infesting Grain Sorghum in 
Georgia and Texas. Journal of Entomological Science, 53, 104-106. https://doi.org/10.18474/JES17-116.1

[20] Manfrino, R.G., Zumoffen, L., Salto, C.E. and Lopez, L.C.C. (2014) Natural Occurrence of Entomophthoroid Fungi of Aphid Pests on Medicago sativa L. in Argentina. Revista Argentina de Microbiología, 46, 49-52. https://doi.org/10.1016/S0325-7541(14)70048-3

[21] Vanderlip, R.L. and Reeves, H.E. (1972) Growth Stages of Sorghum [Sorghum bicolor (L.) Moench]. Agronomy Journal, 64, 13-16. https://doi.org/10.2134/agronj1972.00021962006400010005x

[22] Papierok, B. and Hajek, A.E. (1997) Fungi: Entomophthorales. In: Lacey, L.A., Ed., Manual of Techniques in Insect Pathology, Academic Press, New York, 87-212. https://doi.org/10.1016/B978-012432555-5/50012-9

[23] Fargues, J., Bon, M.C., Manguin, S. and Couteaudier, Y. (2002) Genetic Variability among Paecilomyces fumosoroseus Isolates from Various Geographical and Host Insect Origins Based on the rDNA-ITS Regions. Mycological Research, 106, 1066-1074. https://doi.org/10.1017/S0953756202006408

[24] White, T.J., Bruns, T.D., Lee, S. and Taylor, J. (1990) Amplification and Direct Sequencing of Fungal Ribosomal RNA Genes for Phylogenetics. In: Innis, M.A., Gelfad, D.H., Sninsky, J.J. and White, T.J., Eds., PCR Protocols, Academic Press, San Diego, 315-322.

[25] Lu, L., Cheng, B., Du, D., Hu, X., Peng, A., Pu, X., Zhang, X., Huang, Z. and Chen, G. (2015) Morphological, Molecular, and Virulence Characterization of Three Lecanicillium Species Infecting Asian Citrus Psyllids in Huangyan Citrus. Journal of Invertebrate Pathology, 125, 45-55. https://doi.org/10.1016/j.jip.2015.01.002

[26] Ghikas, D.V., Kouvelis, V.N. and Typas, M.A. (2010) The Complete Mitochondrial Genome of the Entomopathogenic Fungus Metharizium anisopliae var. anisopliae, Gene Order and trn Gene Clusters Reveal a Common Evolutionary Course for All Sordariomycetes. Archives of Microbiology, 185, 393-401. https://doi.org/10.1007/s00203-006-0104-X

[27] Rehner, S.A., Posada, F., Buckley, E.P., Infante, F., Castillo, A. and Vega, F.E. (2006) Phylogenetic Origins of African and Neotropical Beauveria bassiana s. l. Pathogens of the Coffee Borer, Hypothenemus hampei. Journal of Invertebrate Pathology, 93, 11-21. https://doi.org/10.1016/j.jip.2006.04.005

[28] Nikoh, N. and Fukatsu, T. (2000) Inter-Kingdom Host Jumping Underground: Phylogenetic Analysis of Entomoparasitic Fungi of the Genus Cordyceps. Molecular Biology and Evolution, 17, 629-638. https://doi.org/10.1093/oxfordjournals.molbev.a026341

[29] Hall, T.A. (1999) BioEdit: A User-Friendly Biological Sequence Alignment Editor and Analysis Program for Windows 95/98/NT. Nucleic Acids Symposium Series, 41, 95-98.

[30] Kumar, S., Stecher, G. and Tamura, K. (2016) MEGA 7: Molecular Evolutionary Genetics Analysis Version 7.0. for Bigger Datasets. Molecular Biology and Evolution, 33, 1870-1874. https://doi.org/10.1093/molbev/msw054

[31] Felsenstein, J. (1985) Confidence Limits on Phylogenies: An Approach Using the Bootstrap. Evolution, 39, 783-791. https://doi.org/10.1111/j.1558-5646.1985.tb00420.x

[32] Zare, R. and Gams, W. (2008) A Revision of the Verticillium fungicola Species Complex and Its Affinity with the Genus Lecanicillium. Mycological Research, 112, 811-824. https://doi.org/10.1016/j.mycres.2008.01.019 
[33] Carneiro, A.A., Gomes, E.A., Teixeira, G.C., Tavares, F.F., Carneiro, P.N. and Cruz, I. (2008) Molecular Characterization and Pathogenicity of Isolates of Beauveria spp. to Fall Armyworm. Pesquisa Agropecuária Brasileira, 4, 513-520. https://doi.org/10.1590/S0100-204X2008000400010

[34] Rehner, S.A., Minnis, A.M., Sung, G.H., Luangsa-ard, J.J., Devotto, L. and Humber, R.A. (2011) Phylogeny and Systematics of the Anamorphic, Entomopathogenic Genus Beauveria. Mycologia, 103, 1055-1073. https://doi.org/10.3852/10-302

[35] Kulu, I.P., Abadi, A.L., Afandhi, A. and Nooraidawati (2015) Morphological and Molecular Identification of Beauveria bassiana as Entomopathogen Agent from Central Kalimantan Peatland, Indonesia. International Journal of ChemTech Research, 8, 2079-2084.

[36] Shimazu, M. and Takatsuka, J. (2010) Isaria javanica (Anamorphic Cordycipitaceae) Isolated from Gypsy Moth Larvae, Lymantria dispar (Lepidoptera: Lymantriidae), in Japan. Applied Entomology and Zoology, 45, 497-504. https://doi.org/10.1303/aez.2010.497

[37] Gallou, A., Serna, D.M.G., Berlanga, P.A.M., Ayala, Z.M.A., Mellín, R.M.A., Montesinos, M.R. and Arredondo, B.H.C. (2016) Species Clarification of Isaria Isolates Used as Biocontrol Agents against Diaphorina citri (Hemiptera: Liviidae) in Mexico. Fungal Biology, 120, 414-423. https://doi.org/10.1016/j.funbio.2015.11.009

[38] Ramanujam, B., Balachander, M., Roopa, G., Rangeshwaran, R. and Karmakar, P. (2011) ITS Sequencing of Indian Isolates of Lecanicillium Species. Journal of Biological Control, 25, 337-341.

[39] Sugimoto, M., Koike, M., Hiyama, N. and Nagao, H. (2003) Genetic, Morphological, and Virulence Characterization of the Entomopathogenic Fungus Verticillium lecanii. Journal of Invertebrate Pathology, 82, 176-187. https://doi.org/10.1016/S0022-2011(03)00014-4

[40] D’Alessandro, C.P.D., Jones, L.R., Humber, R.A., López, L.C.C. and Sosa, G.D.R. (2013) Characterization and Phylogeny of Isaria spp. Strains (Ascomycota: Hypocreales) Using ITS1-5.8S-ITS2 and Elongation Factor 1-Alpha Sequences. Journal of Basic Microbiology, 53, 1-11.

[41] Meyling, N.V., Pilz, C., Keller, S., Widmer, F. and Enkerli, J. (2012) Diversity of Beauveria spp. Isolates from Pollen Beetles Meligethes aeneus in Switzerland. Journal of Invertebrate Pathology, 109, 76-82. https://doi.org/10.1016/j.jip.2011.10.001

[42] Fadayivata, S., Moravvej, G. and Karimi, J. (2014) Pathogenicity of the Fungus Lecanicillium longisporum against Sipha maydis and Metopolophium dirhodum in Laboratory Conditions. Journal of Plant Protection Research, 54, 67-73. https://doi.org/10.2478/jppr-2014-0010

[43] Jaronski, S.T. (2010) Ecological Factors in the Inundative Use of Fungal Entomopathogens. BioControl, 55, 159-185. https://doi.org/10.1007/s10526-009-9248-3

[44] Ormond, E.L., Thomas, A.P., Pugh, P.J., Pell, J.K. and Roy, H.E. (2010) A Fungal Pathogen in Time and Space: The Population Dynamics of Beauveria bassiana in a Conifer Forest. FEMS Microbiology Ecology, 74, 146-154. https://doi.org/10.1111/j.1574-6941.2010.00939.x

[45] Vargas, T.V., Hernández, R.M.E., Gutiérrez, L.J., Plácido, D.C.J. and Jiménez, C.A. (2007) Climatic Classification of Tamaulipas State, México. CienciaUAT, 2, 15-19.

[46] CONABIO (Comisión Nacional para el Conocimiento y Uso de la Biodiversidad). http://www.conabio.gob.mx/informacion/metadata/gis/climalmgw.xml

[47] Cabanillas, H.E. and Jones, W.A. (2009) Effects of Temperature and Culture Media 
on Vegetative Growth of an Entomopathogenic Fungus Isaria sp. (Hypocreales: Clavicipitaceae) Naturally Affecting the Whitefly Bemisia tabaci in Texas. Mycopathologia, 167, 263-271. https://doi.org/10.1007/s11046-008-9176-2

[48] Hajek, A.E. and St. Leger, R.J. (1994) Interactions between Fungal Pathogens and Insect Host. Annual Review of Entomology, 39, 293-322.

https://doi.org/10.1146/annurev.en.39.010194.001453

[49] Inglis, G.D., Goettel, M.S., Butt, T.M. and Strasser, H. (2016) Fungi as Biocontrol Agents: Progress, Problems and Potential. In: Butt, T.M., Jackson, C. and Magan, N., Eds., Use of Hyphomycetous Fungi for Managing Insect Pests, Wallingford, 23-69.

[50] Bouamama, N., Vidal, N. and Fargues, J. (2010) Effects of Fluctuating Moisture and Temperature Regimes on the Persistence of Quiescent Conidia of Isaria fumosorosea. Journal of Invertebrate Pathology, 105, 139-144.

https://doi.org/10.1016/j.jip.2010.05.014 